\title{
Monitoring the fluvial palynomorph load in a lowland temperate catchment and its relationship to suspended sediment and discharge
}

\author{
A. G. Brown $\cdot$ R. G. Carpenter $\cdot$ D. E. Walling
}

Received: 17 April 2007/Revised: 26 February 2008/Accepted: 3 March 2008/Published online: 29 March 2008

(C) Springer Science+Business Media B.V. 2008

\begin{abstract}
Despite it being a component of the seston we know very little about fluvial (waterborne) pollen and spore (palynomorph) transport. This paper presents the results of a monitoring programme conducted over two years and at a catchment scale in South West England. A hierarchical monitoring network was established with flood peak samples taken at 9 sub-catchments, intra-hydrograph samples taken in two sub-catchments and time-integrated sampling undertaken at one location. In addition sampling was undertaken of probable palynomorph sources such as channel bed and bank sediments, and the airborne pollen flux was monitored using modified Tauber traps. The results support previous research in illustrating how the vast majority of fluvial pollen and
\end{abstract}

Handling editor: J. Saros

A. G. Brown $(\bowtie)$

School of Geography, Palaeoecology Laboratory

University of Southampton, Highfields Campus,

University of Southampton, Southampton SO17 1BJ, UK

e-mail: a.g.brown@soton.ac.uk;

Tony.Brown@soton.ac.uk

R. G. Carpenter

South West Water Limited, Peninsula House, Rydon

Lane, Devon, Exeter EX2 7HR, UK

D. E. Walling

School of Geography and Archaeology, University of Exeter, Amory Building, Rennes Drive, Exeter EX4 4RJ, UK spores are transported during floods (91\%) and that the main control on waterborne palynomorph assemblages is the catchment vegetation and its spatial distribution but with a long-distance (extra-catchment) component. However, strong seasonal effects are also shown, and the importance of distinctive sources such as the riparian input, bed re-suspension and overland flow into drains and tributaries is revealed. Fine sediment in river pools appears to act as a selective store of damaged cereal type pollen grains derived from arable fields. Although pollen does form part of composite particles the data presented here suggest that the majority of the pollen is transported as single grains. Fluvial palynomorph loading is strongly dependant upon discharge and so concentrations in laminated or varved sediments could be regarded as a proxy for flood magnitude.

Keywords Seston - Fine particulate organic matter · Waterborne pollen - Suspended sediment . organic transport

\section{Introduction}

Pollen and spores, here collectively referred to as palynomorphs, are a persistent component of river seston or fine particulate organic matter (FPOM) and part of the flux linking upstream and downstream reaches of river ecosystems. Artificially introduced 
pollen has also been used as a seston analogue (Miller \& Georgian, 1992) without much knowledge of the transport characteristics of palynomorphs. Rivers are also the major source of palynomorphs input into most lakes and near-shore marine sediments (Federove, 1952; Peck, 1973; McAndrews \& Power, 1973; Crowder \& Cuddy, 1973; Pennington, 1979; Bonny, 1980; Brown, 1985; Fall, 1987; David \& Roberts, 1990; Traverse, 1992, 1994), but are far less well understood than the airborne component. The aim of the monitoring project reported here was to understand the relationship of palynomorph transport to river discharge, their relationship to the transport and deposition of suspended sediment and thereby investigate their possible use as natural sediment tracers.

Studies of fluvial pollen and spore transport are rare but have revealed that flood concentrations can be from $100,000 \mathrm{~g} \mathrm{ml}^{-1}$ (Peck, 1974) to as high as 130,000-230,000 $\mathrm{g} \mathrm{ml}^{-1}$ (Brown, 1985). Pollen and spores transport has also been investigated in flumes (Brush \& Brush, 1972), and Holmes (1990) reported no differential sorting at velocities over $0.30 \mathrm{~m}^{-1} \mathrm{~s}^{-1}$ (Holmes, 1990; 1994). Meade et al. (1990) also report that flood-borne pollen is well mixed. It is widely accepted that the majority of pollen and spores entering small lakes and ponds are derived from headwaters along with the rest of the seston, and that the ratio of fluvial to airborne input depends on the size of the catchment, the lake surface area, the topography and the catchment vegetation. In classic studies Peck $(1973,1974)$ found $97 \%$ of the pollen and spore input to Oakdale reservoir was fluvial, and Bonny (1978) found $87 \%$ of the input to Blelham Tarn was of fluvial origin. However, little is known of the seasonal variation in this component of the seston, its transport and its storage within the stream system.

We can define the fluvial palynomorph flux $\left(F_{1}\right)$ as being the combination of several distinct components:

$\mathrm{F}_{1}=\mathrm{Q}\left(\mathrm{A}_{\mathrm{c}}+\mathrm{R}_{\mathrm{c}}+\mathrm{O}_{\mathrm{c}}+\mathrm{B}_{\mathrm{c}}+\Delta \mathrm{S}_{\mathrm{c}}\right)$

where $Q$ is the stream discharge in $\mathrm{m}^{3} \mathrm{~s}^{-1}$ and $A_{c}$ is the direct airborne component which includes the extra local and regional component (sensu Jacobsen \& Bradshaw, 1981) and which is proportional to channel area, $R_{c}$ is the riparian local component, $O_{c}$ is the direct overland flow component, $B_{c}$ is the bank erosion component and $S_{c}$ is river storage in bed sediments which can be re-suspended during floods (all in grains $1^{-1}$ ). Using the analogy with forest gaps and lakes (Jacobsen \& Bradshaw, 1981) for rivers less than $30 \mathrm{~m}$ wide the significant terms can be reduced to $R_{c}, O_{c}$ and $S_{c}$. This is because at this scale $\mathrm{A}_{\mathrm{c}}$ would be proportionately minor due to a very small unimpeded direct fall area. However, it is this fraction $\left(\mathrm{A}_{\mathrm{c}}\right)$ that has been modelled to produce quantitative estimates of vegetation cover (Prentice \& Parsons, 1983; Prentice, 1985, 1986, 1988; Sugita et al. 1999). It can also be assumed that the bank erosion $\left(B_{c}\right)$ component would be quantitatively small due to the low concentrations of pollen in clastic sediments and the non-organic-rich horizons of soils (Brown, 1985), although it might be important in the composition of the palynomorph assemblage. However, there is little data on the relative input of these components and the sampling strategy employed in this study was designed to allow some quantification of these different input sources.

\section{Study site and methods}

The site chosen for this study was the Exe Basin in SW England (Fig. 1). The River Exe drains an area of $1,530 \mathrm{~km}^{2}$; its source rises at Exe Head on Dure Down, Exmoor (SS 752 415) and flows $87.2 \mathrm{~km}$ west and south until it reaches the Exe Estuary at Exmouth. The Exe catchment was chosen for this study as it exhibits considerable diversity with regards to vegetation cover, hydrological regimes and climatic conditions (Walling \& Moorehead, 1987). Thirteen sub-catchments were monitored (data from 9 is used here) to sample this variety. Within the Exe catchment there is an established hydrometric monitoring network operated by the University of Exeter and the Environment Agency, providing suitable monitoring data along with the availability of meteorological data supplied by the British Atmospheric Data Centre. Finally, the Exe catchment has been extensively studied and there is subsequently a large amount of literature relating to catchment sediment dynamics (for example Walling \& Webb, 1981; Walling \& Woodward, 1993; Walling et al., 1993; Walling \& He, 1994; Nicholas \& Walling, 1995; Collins et al., 1997a, b; Blake et al., 2002; Collins \& Walling, 2002). The geology of the catchment is dominated by Devonian sandstones, slates and conglomerates in the north, and 
Fig. 1 The location of the Exe basin and the subcatchments monitored as part of this study

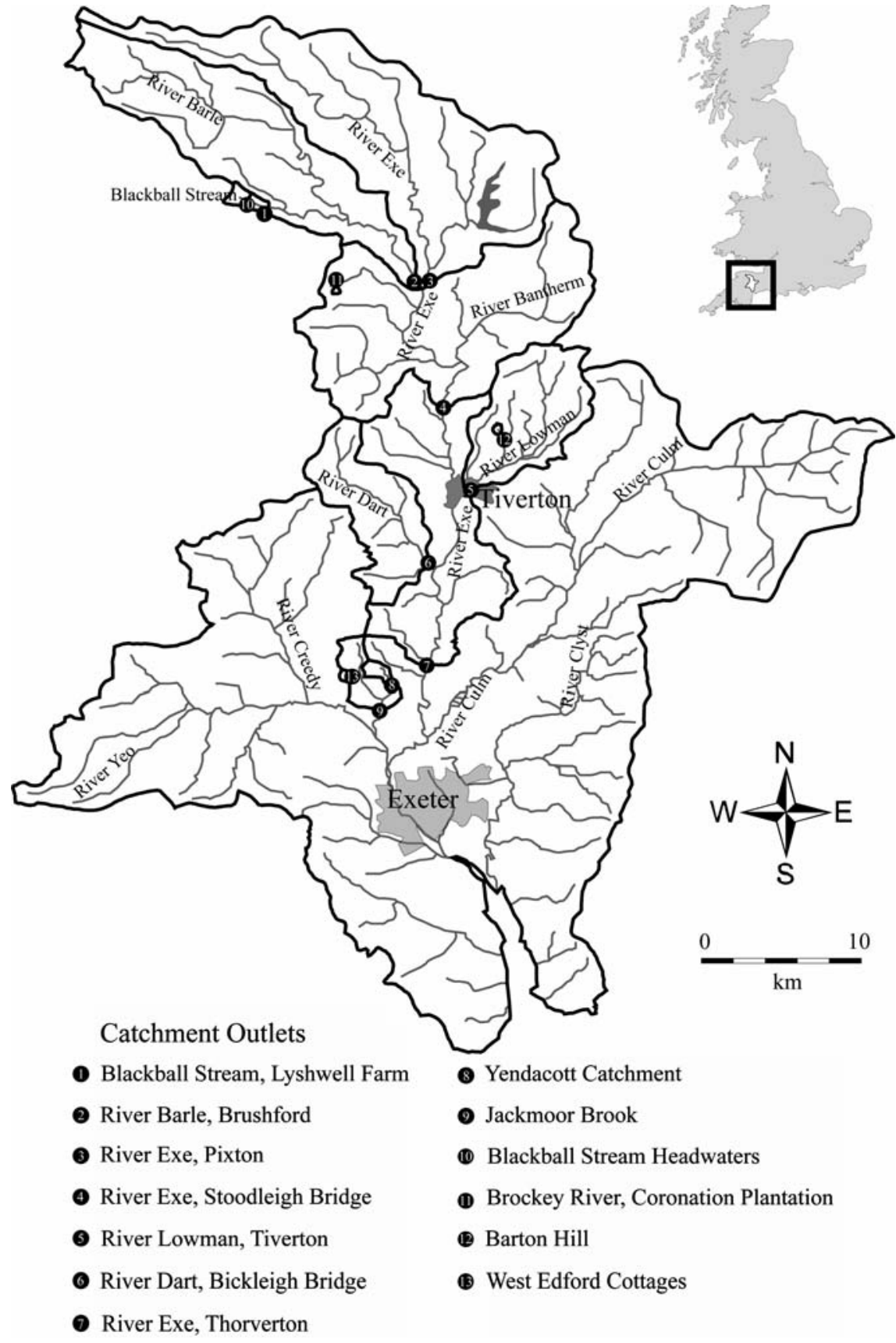

Carboniferous sandstones, conglomerates and mudstones in the middle and south with one area of Cretaceous Upper greensand in the east. The catchment lay outside the maximum Pleistocene glacial limits and has a well-developed strath terrace staircase and basin and gorge type floodplain. The relative relief of the catchment is $519 \mathrm{~m}$ and slopes are steepest in the headwaters. The average slope angle is $17^{\circ}$ (Webb, 1980), but with considerable variation in the sub-catchments (Table 1). The catchment has a mean annual precipitation of $1,097 \mathrm{~mm}$ but this also varies in the sub-catchments from 900-3262 $\mathrm{mm} \mathrm{yr}^{-1}$. The mean daily flow at Thorverton is $9 \mathrm{~m}^{3} \mathrm{~s}^{-1}$ with 0.01 probability of exceedance flow being $90 \mathrm{~m}^{3} \mathrm{~s}^{-1}$ and the 0.99 probability being $1.4 \mathrm{~m}^{3} \mathrm{~s}^{-1}$. 
Table 1 Topographic statistics for the study catchments taken from the Flood Estimation Handbook CD-ROM (Centre for Ecology and Hydrology, 2002)

\begin{tabular}{|c|c|c|c|c|c|c|c|c|}
\hline \multicolumn{2}{|c|}{ Catchment } & \multirow{2}{*}{$\begin{array}{r}\begin{array}{l}\text { Area } \\
\left(\mathrm{km}^{2}\right)\end{array} \\
1.8\end{array}$} & \multirow{2}{*}{$\begin{array}{l}\text { Max. drainage } \\
\text { Path }(\mathrm{km}) \\
2.88\end{array}$} & \multirow{2}{*}{$\frac{\begin{array}{l}\text { Mean slope } \\
(\mathrm{m} / \mathrm{km})\end{array}}{66.9}$} & \multirow{2}{*}{$\frac{\begin{array}{l}\text { Mean } \\
\text { aspect }\left({ }^{\circ}\right)\end{array}}{93}$} & \multirow{2}{*}{$\begin{array}{l}\begin{array}{l}\text { Catchment } \\
\text { outlet altitude (m O.D.) }\end{array} \\
287\end{array}$} & \multirow{2}{*}{$\begin{array}{l}\text { Mean altitude } \\
\text { (m O.D.) }\end{array}$} & \multirow{2}{*}{$\begin{array}{l}\text { Max. altitude } \\
\text { (m O.D.) } \\
378\end{array}$} \\
\hline 1 & Lyshwell Farm & & & & & & & \\
\hline 2 & Brushford & 128.8 & 40.99 & 136.4 & 152 & 128 & 245 & 488 \\
\hline 3 & Pixton & 149.8 & 36.79 & 153.8 & 185 & 128 & 307 & 519 \\
\hline 4 & Stoodleigh & 420.7 & 55.44 & 142.5 & 168 & 74 & 284 & 519 \\
\hline 5 & Tiverton & 54.5 & 15.87 & 95.1 & 192 & 62 & 168 & 286 \\
\hline 6 & Bickleigh & 45.4 & 14.33 & 146.2 & 132 & 52 & 176 & 271 \\
\hline 7 & Thorverton & 608.9 & 76.92 & 137.8 & 164 & 26 & 244 & 519 \\
\hline 8 & Yendacott & 1.5 & 2.38 & 48.9 & 161 & 35 & 59 & 85 \\
\hline 9 & Pyne cottage & 9.3 & 5.48 & 58 & 158 & 25 & 66 & 235 \\
\hline
\end{tabular}

Vegetation cover and land use was extracted from the Land Cover Map of Great Britain (1990) produced from Landsat Thematic Data (Fuller et al., 1994). This allowed the land use in each of the subcatchments to be quantified. Four types of catchment were identified, predominantly pasture and heathland (sub-catchments 1-3), predominantly pasture and deciduous woodland (sub-catchments 4,6), predominantly pasture and arable (catchments 5,7) and predominantly arable cultivation (catchments 8,9).

Peak flow samples were taken from the outlet of each of the sub-catchments during floods over a period of 24 months. In addition, background lowflow samples were collected, and at two stations samples were taken through storm events (hydrograph samples). Samples were taken either using a submersible pump and portable generator or by hand from the middle of the river at an approximate height of $0.6 \times$ the maximum river depth. This was done in order to ensure that the water was fully mixed and avoided the problem of surface water assemblages being biased towards more buoyant and unsaturated pollen grains (Hopkins, 1950; Traverse and Ginsburg, 1966; Traverse, 1988). This assumption was also tested by sampling a depth profile at an intermediate flow (see results). The volume of water samples was varied depending upon the suspended sediment concentration from as much as 101 at sites with low concentrations (e.g. catchment 1, Lyshwell Farm) to only 21 (Catchment 9, Pyne Cottage). This was estimated from standard 10-1 samples taken during the first two floods.
In addition samples were taken of the bed sediment in a pool and riffle using a 1-m-high steel cylinder pushed into the bed and the water agitated before sampling (Lambert and Walling, 1988). This sediment re-suspension technique was adopted to sample the pollen which could be re-suspended during a flood event. Eight samples were also taken from an actively eroding river bank in the Bickleigh reach of the River Dart (sub-catchment 6) which is both typical of the catchment and central. All the water samples were filtered (some after centrifugation at $2500 \mathrm{rpm}$ for 10 minutes as per standard palynomorph processing (Moore et al., 1991)) using glass fibre Whatman filters (GF/A) with a pore size of $1.6 \mu \mathrm{m}$. The filters were than oven dried and the suspended sediment weight recorded before they were subjected to a standard chemical processing using hydrofluoric acid digestion followed by acetolysis. Pollen concentrations were determined by the addition of Lycopodium clavatum tablets containing a known number of spores (Stockmarr, 1971). Pollen identification routinely used $500 \times$ magnification with $1000 \times$ magnification for small and difficult types with reference to standard keys (Andrew, 1984; Faegri and Iversen, 1989; Moore et al., 1991) and the Exeter University Pollen and Spore reference collection. Pollen and spore nomenclature follows Bennett et al. (1994). Pollen preservation was recorded using a threefold classification adapted from Delcourt and Delcourt (1980); corroded, degraded and mechanically damaged. Where more then one form of degradation was present only the most developed was recorded. 
At each of the sub-catchment sampling stations airborne pollen flux was also monitored using a modified Tauber trap (Tauber, 1974; Hicks and Hyvaarinen, 1986) with a central aperture of $5-\mathrm{cm}$ diameter and sloping collar of $15-\mathrm{cm}$ diameter. The traps were located in an open area of at least $30-\mathrm{m}$ diameter. The traps were not meshed and the samples were processed in the same way as the water and bank samples with hydrofluoric acid digestion followed by acetolysis.

To be able to compare the pollen data with the land use data and identify sources it was necessary to convert the pollen and spore data into 8 vegetation/ land use classes (Table 2). This is inevitably imperfect due to problems of taxonomic precision, but was done using the ecology of the majority species in each of the pollen types sensu Bennett (1994). There are clearly some species of a different ecology within these groups, but the overwhelming majority in pollen producing terms will have been derived from that vegetation type (e.g. Ranunculus includes aquatic species but the vast majority of pollen will be from pasture species). The procedure is described in more detail in Brown et al. (2007) which also related the palynomorph-derived vegetation classes to the subcatchment land use as determined using the Landsat Thematic Data.

\section{Results}

Pollen and spore hydrographs

Sampling of the vertical water profile (Fig. 2) showed the pollen and spores to be well mixed, but with a distinctly higher concentration $(50 \%-20 \%)$ at the water surface. This has been observed before (see discussion) and validates the unbiased nature of samples taken from a single depth.

Sampling through floods at Bickleigh and Thorverton illustrates the dramatic increase in pollen and spore concentration through the flood hydrograph with peak concentrations at Bickleigh reaching 7,000 grains $1^{-1}$ even on January 23rd 2001 (Fig. 3) and coincident with the peak in discharge and suspended sediment. At Thorverton peak concentration is even higher for the same event reaching 35,000 grains $1^{-1}$ coincident with the peak in suspended sediment but preceding the peak discharge (Fig. 3). Damaged grains show a similar trend, but with the second highest concentration being that of arable types which at Thorverton is lagged behind the other types. These concentrations are too high at 3,700 and 18,000 grains $1^{-1}$, respectively, to simply be derived from the channel bed and banks which never exceed 5,000 grains $1^{-1}$ in total (Fig. 5 and later

Table 2 Simplified land cover and associated pollen taxa

Simplified land cover Associated pollen taxa

class

Disturbed ground

Papaver rhoeas-type, Chenopodiaceae, Urtica-type, Hypericum perforatum-type, Brassicaceae, Apiaceae, Lamiaceae undiff., Mentha-type, Scrophularia-type, Rhinanthus, Valeriana officinalis, Arctium-type, Artemisia-type.

Pasture

Ranunculus, Caryophyllaceae, Polygonum, Rumex acetosella, Rumex acetosa, Umbilicus rupestris-type, Potentilla-type, Astragalus danicus-type, Lotus, Medicago sativa, Trifolium-type, Gentianella campestristype, Plantago lanceolata, Digitalis purpurea-type, Scabiosa columbaria, Cirsium-type, Centaurea nigra, Lactuceae, Solidago virgaurea-type, Aster-type, Poaceae undiff.

Marsh

Sphagnum, Caltha palustris-type, Persicaria bistorta-type, Montia fontana, Filipendula, Gentiana-type, Valeriana dioica, Succisa pretensis, Cyperaceae undiff.

Heath/moorland Lycopodium, Juniperus communis, Betula, Vaccinium-type, Calluna vulgaris, Ulex-type.

Bracken Pteridium aquilinum.

Deciduous woodland Pteropsida monolete undiff., Polypodium, Dryopteris-type, Ulmus, Juglans regia, Fagus sylvatica, Quercus, Alnus glutinosa, Corylus avellana-type, Tilia cordata, Populus, Salix, Rhododendron ponticum, Ribes, Rubus, Rosa, Sorbus-type, Ilex aquifolium, Acer campestre, Hedera helix, Fraxinus excelsior, Sambucus.

Coniferous woodland Abies, Picea, Pinus sylvestris.

Arable Avena-type, Hordeum-type, Secale cereale, Zea mays. 


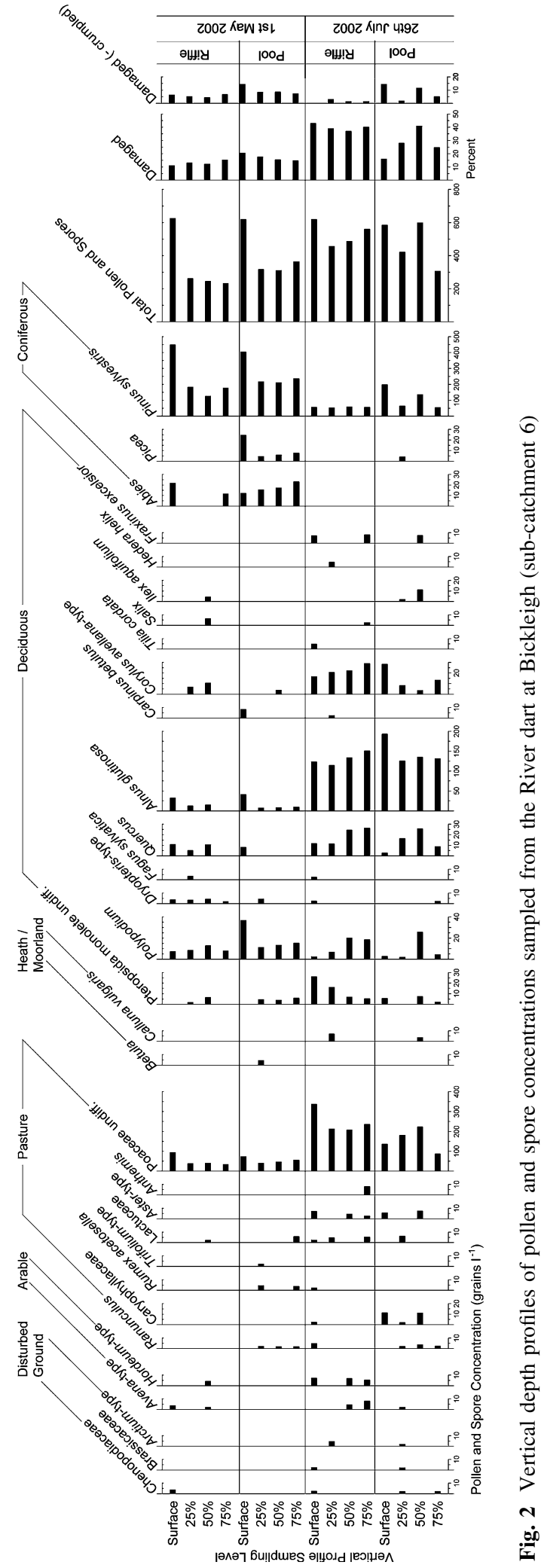

discussion). Integrating over the entire storms these concentrations would require unrealistically large areas of bank erosion to be the main source. Therefore these concentrations must reflect pollen being washed in from other sources such as overland flow into tributaries and drains as well as some riparian washoff. Unsurprisingly spring hydrographs show even higher concentrations reaching 150,000 grains $1^{-1}$ at Bickleigh, but only 7,000 grains $1^{-1}$ at Thorverton (Fig. 3) probably due to the location of the storm over the Dart Catchment. Arable types are again disproportionately high in relation to the percentage of area covered by arable fields in both catchments (Brown et al., 2007). In April peak concentrations reach 22,000 grains $1^{-1}$ with damaged arable types alone reaching 11,000 grains $1^{-1}$ (Fig. 3). Autumn hydrographs (Fig. 3) show a fall in peak concentrations to 7,000 and 50,000 grains $1^{-1}$ and arable types, both undamaged and damaged, become proportionately less important, whilst arboreal types become more important.

The relatively high proportion of damaged grains, and particularly those of the arable group is echoed in the river bed samples (Fig. 4). These show that in the Dart sub-catchment, which is predominantly pasture and woodland, Avena type is the second highest concentration after Poaceae reaching over 1,500 grains $\mathrm{g}^{-1}$ of sediment. Typical rates of suspended sediment concentration of $0.2-2 \mathrm{~g}^{-1}$ could produce re-suspended Avena concentrations of 300-3,000 $\mathrm{g}^{-1}$ in the absence of exhaustion effects. Nearly all these grains which must have been derived from arable fields were broken, crumpled or degraded providing a potential signature of this pollen component $\left(\mathrm{S}_{\mathrm{c}}\right)$. This is an important potential store of pollen and is probably the source for much of the degraded pollen (Fig. 3), particularly the arable pollen, observed in the flood samples.

\section{Bank-erosion-derived input}

The bank sediment component represents the longterm palynomorph store from local vegetation and overbank sedimentation. Due to oxidation-reduction cycles the average proportion of damaged grains (excluding crumpled grains) is higher than the fluvial and bed storage component at $32 \%$ (Fig. 5). The concentrations of the bank samples ranged from 6,300 to 9,300 grains $\mathrm{g}^{-1}$ (mean 7,400 grains $\mathrm{g}^{-1}$ ) 


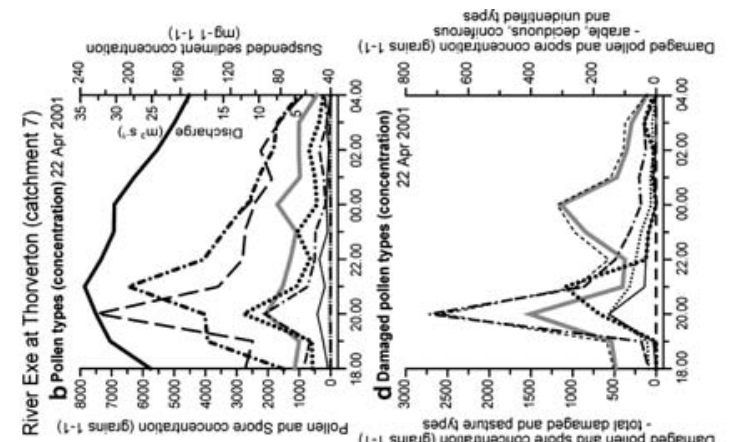

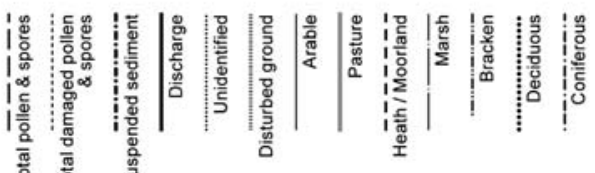

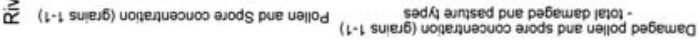

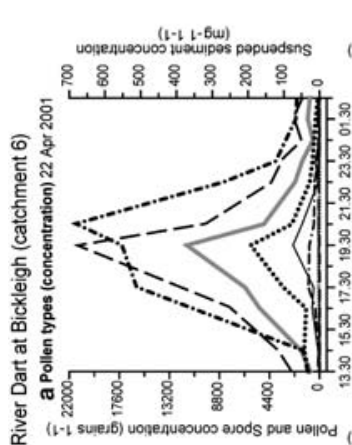

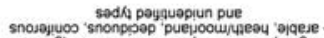
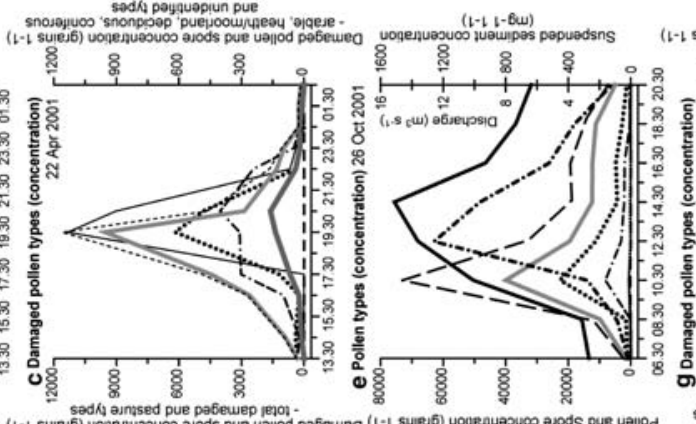

sedis peyguepun pue

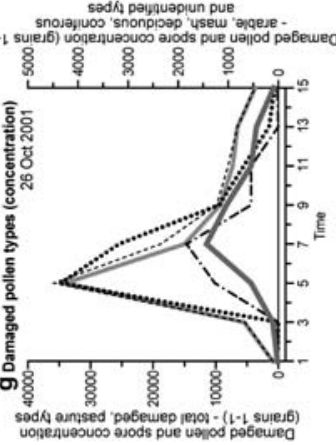

sadk peytuapun pue snowejuos 'snonpirap
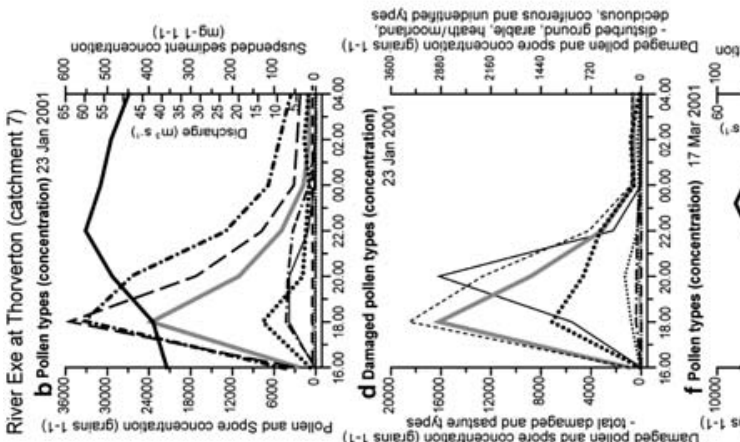

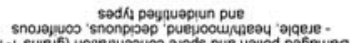

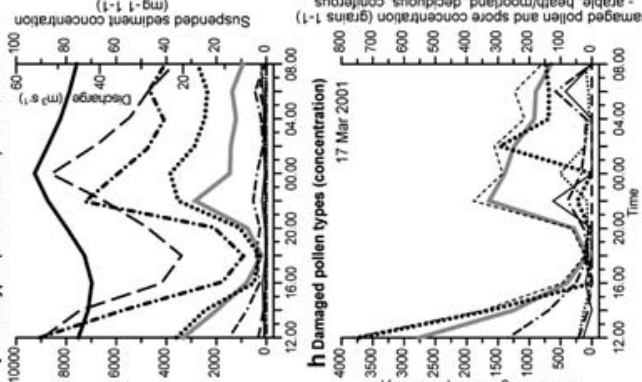

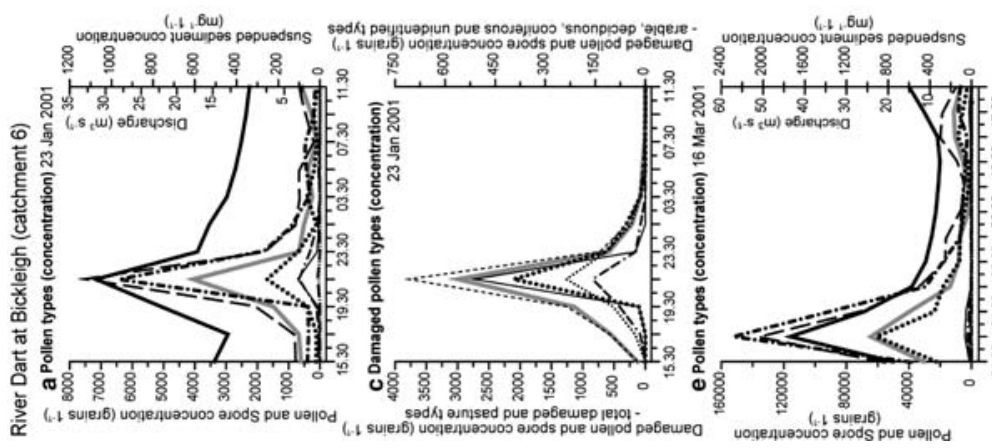

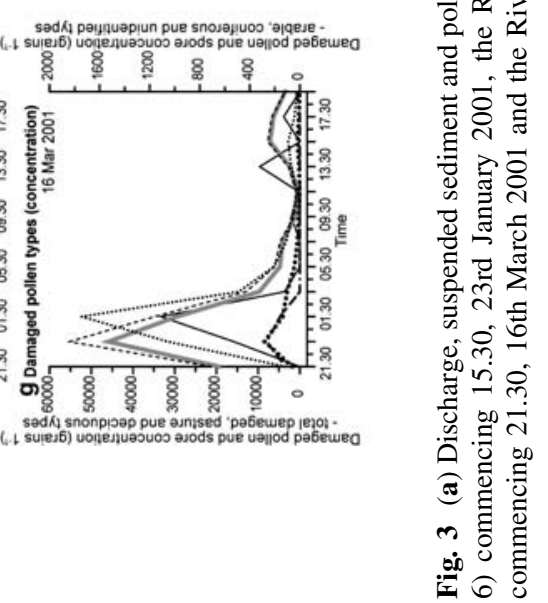



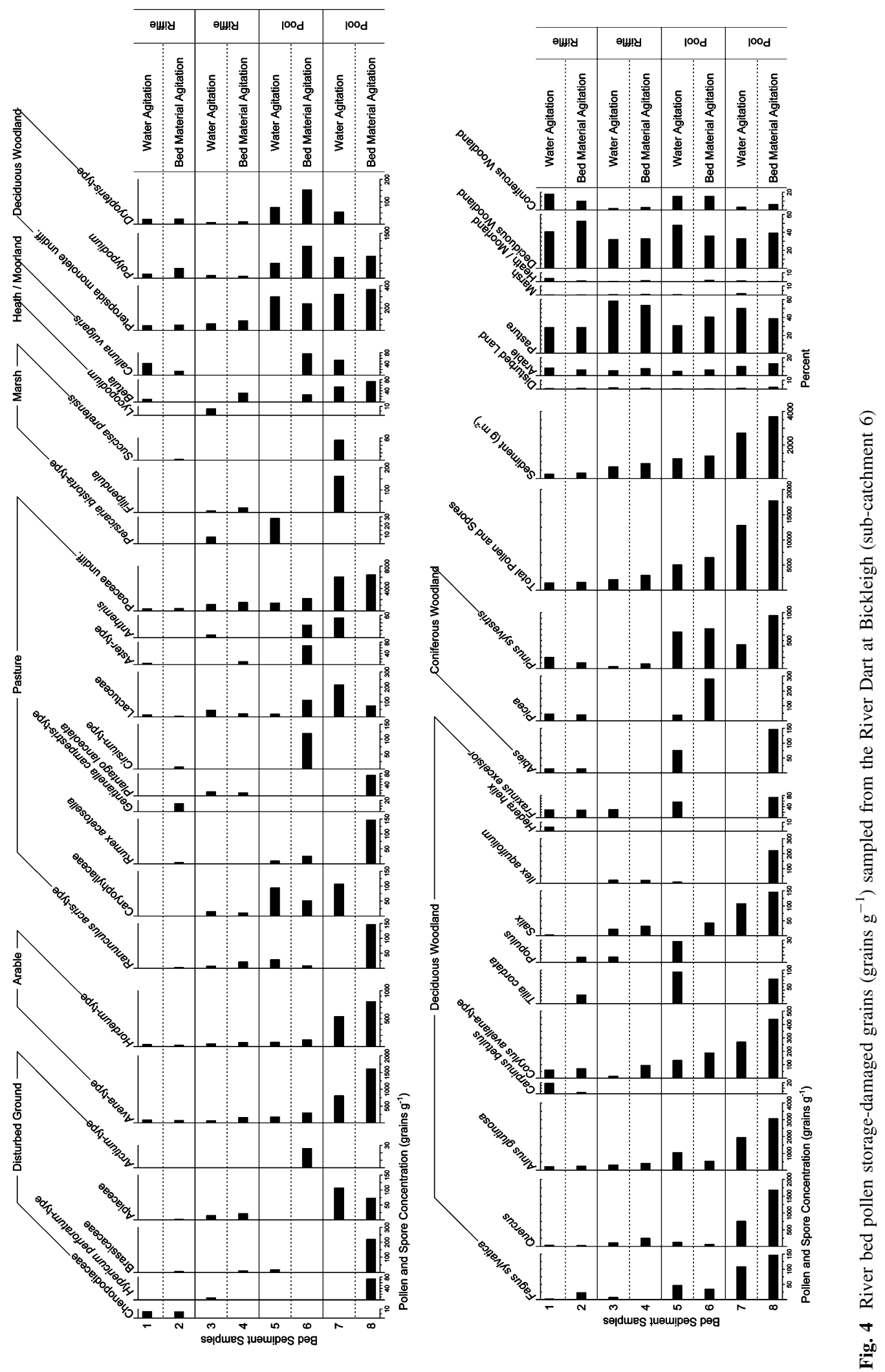

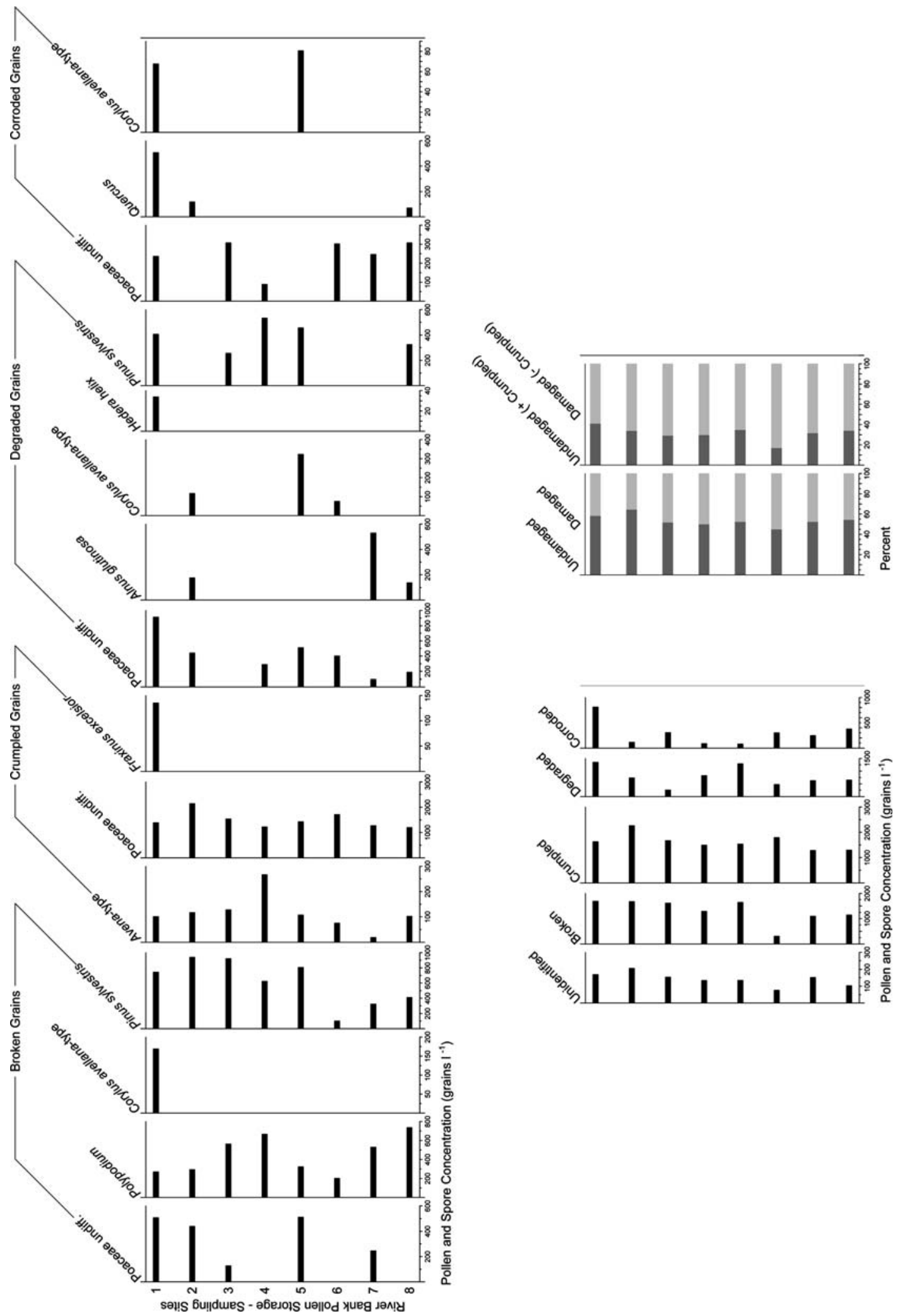

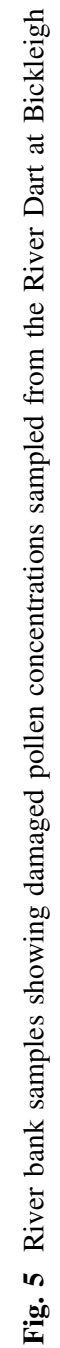



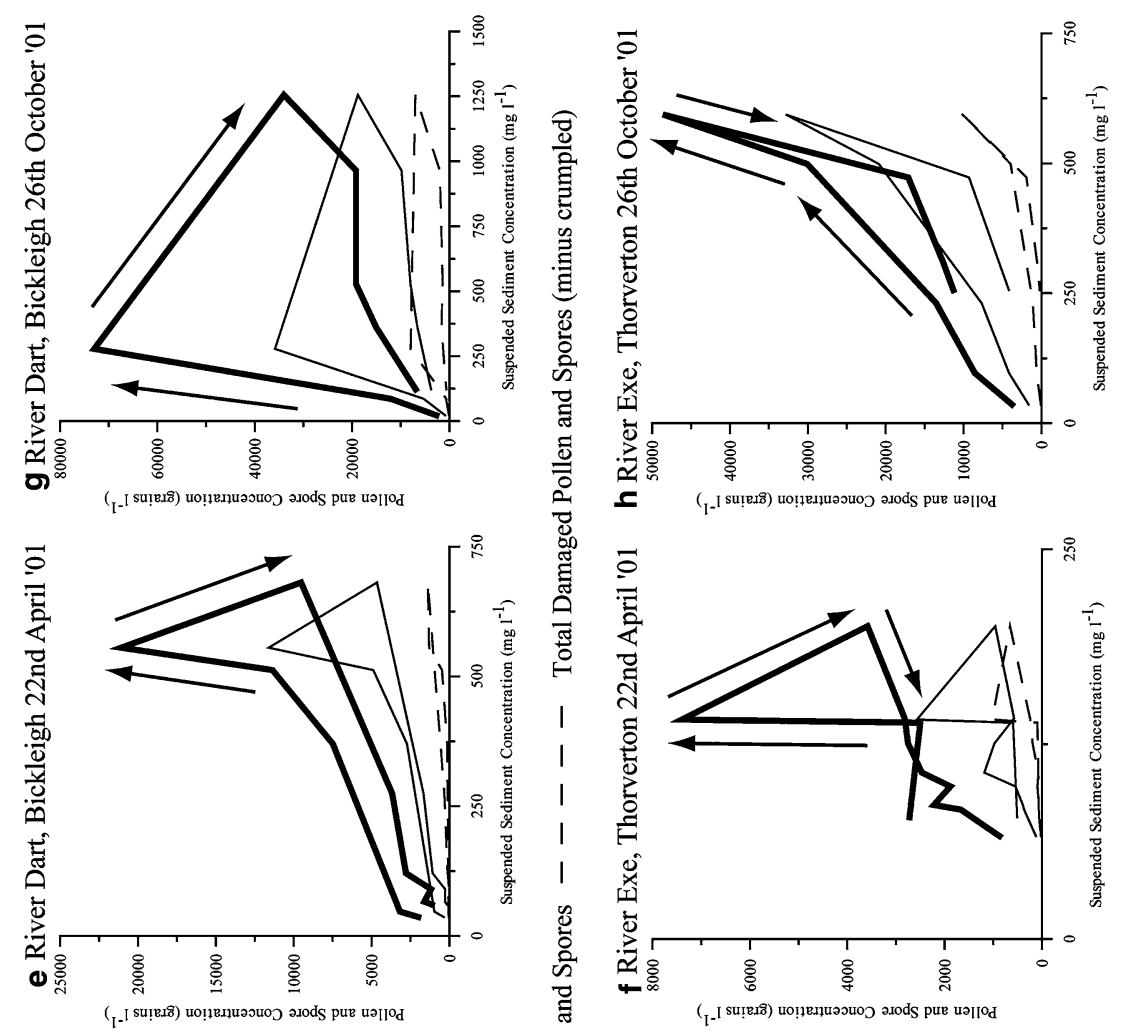

है
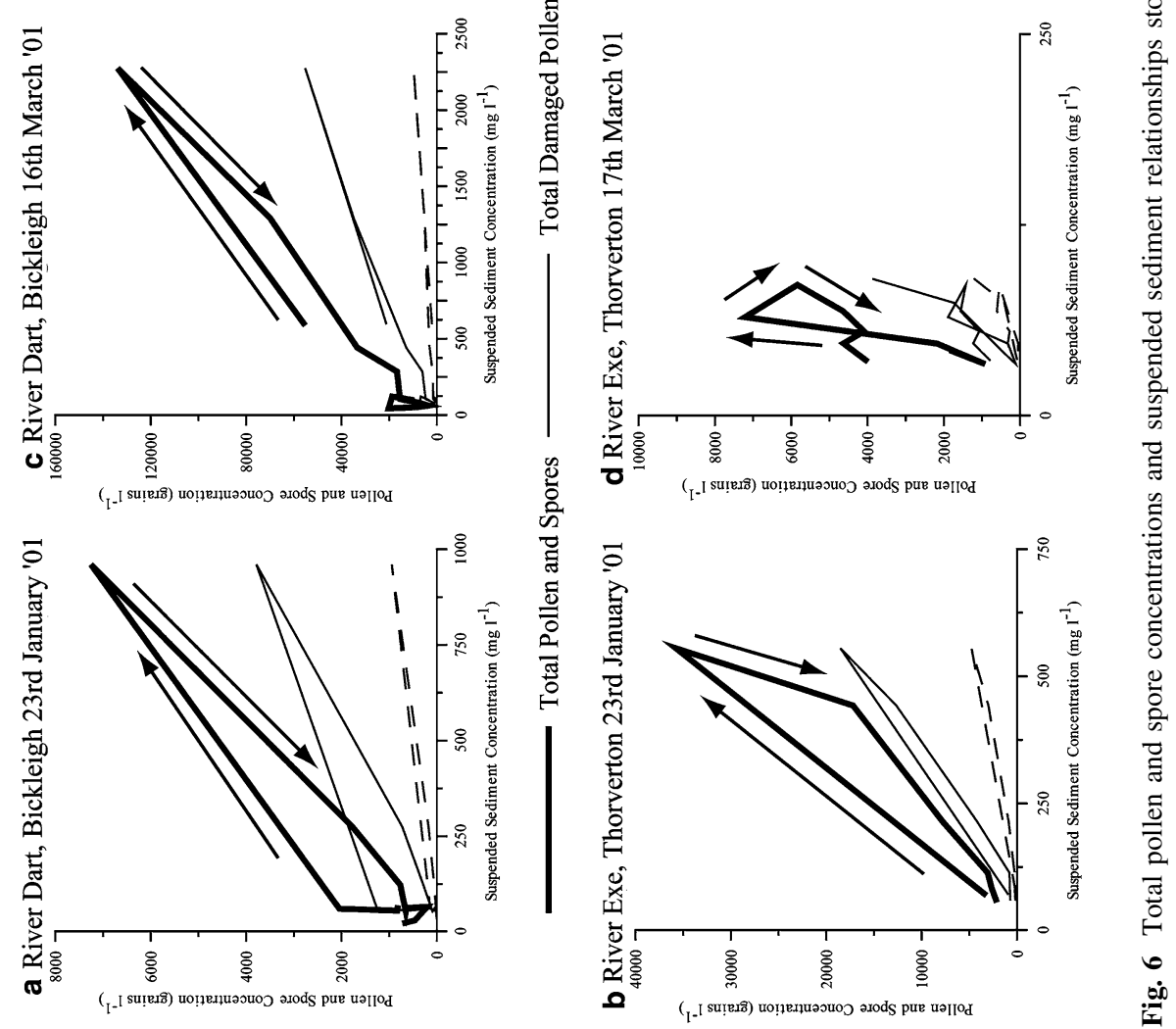
and are similar to the river bar $\left(7,300\right.$ grains $\left.\mathrm{g}^{-1}\right)$ and the channel bed $\left(6,300\right.$ grains $\left.\mathrm{g}^{-1}\right)$ with type diversity also being comparable $(37,40,38$ per 500 pollen grain sum).

\section{Discussion}

The well mixed vertical profile of pollen types but with a higher pollen and spore concentration at the surface has also been reported by Traverse \& Ginsburg (1966) and Traverse (1988) who regarded it as a function of the saturation time of airborne inputs. Starling and Crowder (1981) also observed significantly higher concentrations of pollen towards the surface of the Salmon River; a phenomenon also reported by Smirnov et al. (1996) for the Mississippi River who observed a high degree of variation within the vertical profile (600-2,300 grains $\left.1^{-1}\right)$ with the highest concentrations of two common types, Pinus and Salix, occurring at the surface. Smirnov et al. (1996) suggest that this high surface concentration is due to input from riparian vegetation. However, as Brush \& Brush (1972) have already shown once saturated transport is mixed and unsorted by size or type.

The flood sampling shows that hysteresis plots exhibit variation both site to site and during the year (Fig. 6). Both the March and October loops for Bickleigh show a rapid increase and decrease in discharge and palynomorph concentration, whereas the January plot shows under-sensitivity (Brown \& Quine, 1999) in the palynomorph availability. However, the January plot at Thorverton displays hypersensitivity reaching $35,000 \mathrm{~g}^{-1}$ with only $600 \mathrm{mg}^{-1}$ of suspended sediment followed by exhaustion before the peak discharge has been reached, whereas the March and April loops display a suppressed response. In general the relationship is characterised by clockwise loops (sensu Williams 1989) but counter-clockwise loops do occur especially in the late autumn and early winter due to supply limitation in the non-flowering season.

The bank sediment concentrations are far lower than the airborne influx rate as reported in Brown et al. (2007) which reached as high as 11,400 grains $\mathrm{cm}^{-2} \mathrm{yr}^{-1}$ at Bickleigh (Carpenter, 2005) and the peak flow suspended concentrations presented here. This suggests that the bank erosion contribution is of far lesser quantitative importance at even peak suspended sediment concentrations than the airborne (direct and indirect), riparian and surface wash component. The degraded component of the river bed samples may, however, be preferentially derived from the bank store due to the higher proportion of damaged and degraded grains.

\section{Palynomorph sediment relationships}

As has been shown by the hydrographs (Fig. 3) the peak in palynomorph concentration is often out of phase with the peak in suspended sediment concentration. Plotting palynomorph concentration against suspended sediment concentration provides a variety of hysteresis plots as discussed earlier (Fig. 6). This suggests that much of the palynomorph load is being transported independent of the clastic sediment load. Inverted microscopic examination of flood water samples reveals palynomorph grains transported both as individual grains and as part of composite particles (Fig. 7). Although at the scale of the individual hydrograph there is a strong dependence of palynomorph concentration and discharge overall the relationship is variable as illustrated by the aggregate data from Thorverton (Fig. 8) which although statistically significant shows several data values where the palynomorph concentration greatly exceeds the expected values based upon the general trend. The cause of both this variation and the variable relationship to suspended sediment concentration is the variation in the atmospheric input during the year (Fig. 9). Although it is not possible to use traditional in situ techniques to estimate a palynomorph budget

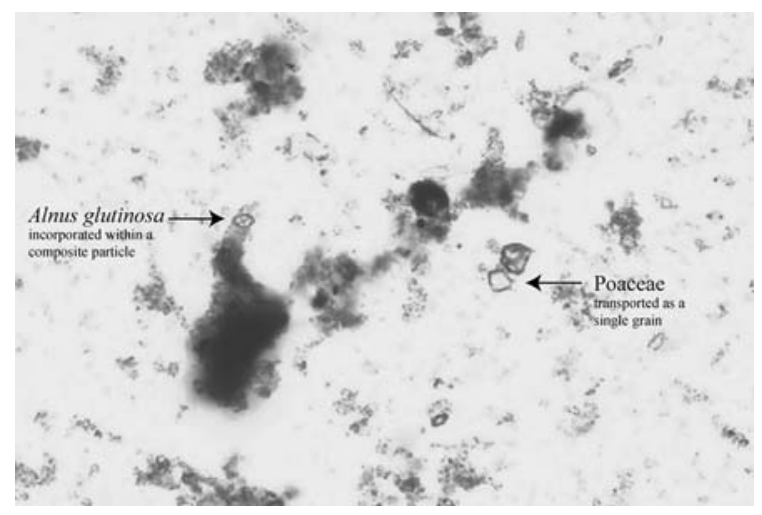

Fig. 7 Pollen grains as both composite particles and as single grains from the River Dart at Bickleigh (catchment 6) 25th July 2003 at peak flow. Picture courtesy of N. Williams 


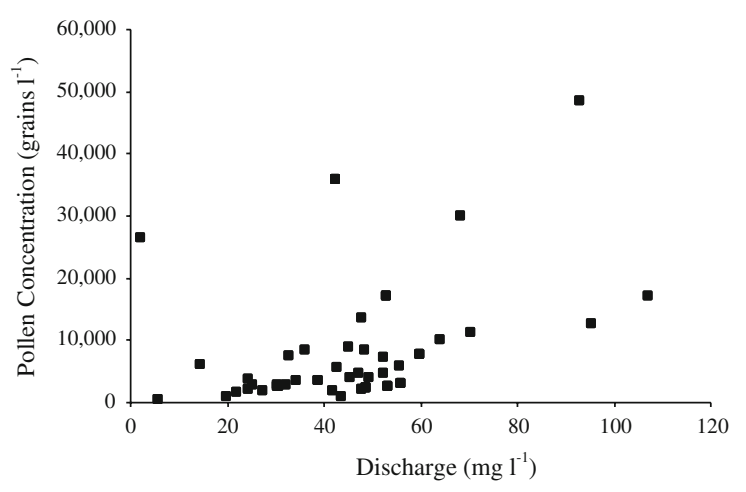

Fig. 8 Plot of discharge against suspended pollen and spore concentration, River Exe, Thorverton

an estimate can be made for Thorverton based upon the average low-flow (Q95) and high-flow concentrations for individual months (Fig. 9). This illustrates the dominance by high flows whereby $91 \%$ of the palynomorph load was transported in 5\% of the year (yearly total). These calculations suggest that approximately $976 \times 10^{12}$ grains were transported out of the Exe catchment between November 2000 and October 2001. Using an average palynomorph size of an equivalent spherical body of $60 \mu \mathrm{m}$ this is only a small proportion of the total suspended sediment at approximately $50 \mathrm{~g}$ over the year.

\section{Conclusions}

This large-scale monitoring of fluvially transport palynomorphs has confirmed a number of previous conclusions derived from the limited monitoring of single sites and occasional observations. Firstly that the palynomorph water depth profile is generally uniform indicating full mixing, except for a surface
Fig. 9 Monthly pollen loading for the River Exe catchment at Thorverton based on $15 \mathrm{~min} \mathrm{Q}$ data and 95\% duration division and the monthly airborne influx as recorded at Brushford (outlet of catchment 2) and Bickleigh (outlet of catchment 6)

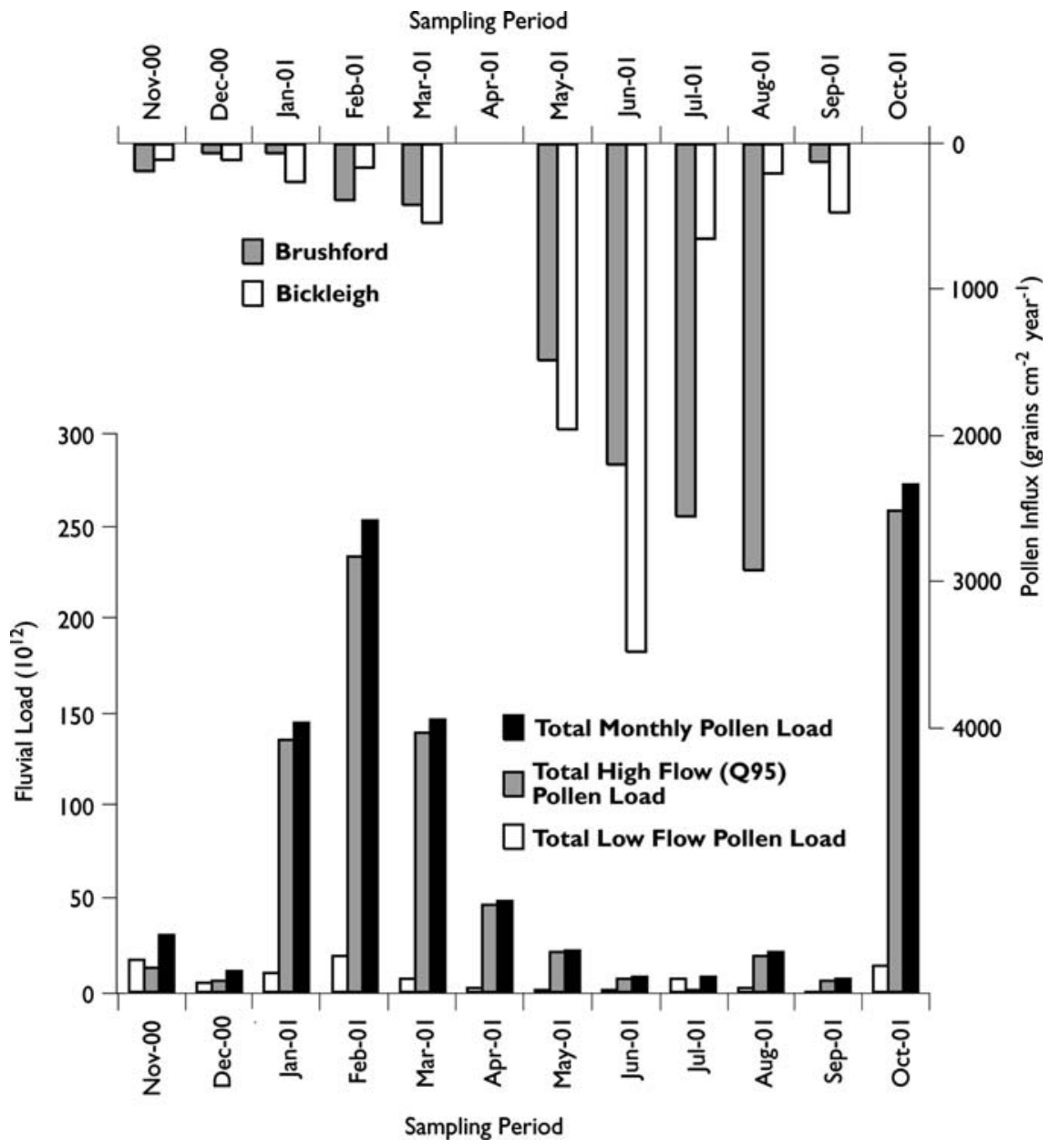


enhancement effect. Secondly that the vast majority of fluvial input in this temperate mixed-land use basin occurs during flood events $(91 \%)$ and thirdly that the overall variation of fluvial input is controlled by the combination of seasonality and the spatial variation in sub-catchment vegetation.

In addition, this study also shows that the strong seasonal effects cause both over and under-representation of catchment vegetation in the fluvial output. These reflect the pathways of palynomorph transport into rivers particularly direct input probably via leafdrip of riparian vegetation, overland flow in autumn and winter, and bed sediment re-suspension. A particularly important finding is the high storage in river pool sediments of arable pollen grains, a high proportion of which are damaged but still recognisable. The exact cause of this is unknown, but it may be due to the greater settling velocity of these large grains on the declining limb of winter and spring hydrographs in areas where there are high levels of arable cultivation upstream of the sampling location. Although direct observations of the seston show that pollen can form part of composite sediment particles the data presented here suggest that the majority of the pollen and spore load is transported as single grains and forms a minor component quantitatively of the seston flux. Fluvial palynomorph loading is strongly dependant upon discharge and so concentrations in laminated or varved sediments could be regarded as a proxy for flood magnitude.

Acknowledgements The authors must thank many members of the Geography Department at Exeter for help with the monitoring and sample processing particularly D. E. Walling, J. Grapes and A. Ames. Additional cartographic help was provided by S. Rouillard and B. Smith. This work was conducted as part of NERC studentship and forms part of the Pollen Monitoring Programme.

\section{References}

Andrew, R., 1984. A practical pollen guide to the British flora. Quaternary Research Association Technical Guide, No. 1,Cambridge.

Bennett K. D., G. Whittington \& K. J. Edwards, 1994. Plant nomenclatural changes and pollen morphology in the British Isles. Quaternary Newsletter 73: 1-6.

Blake, W. H., D. E. Walling \& Q. He, 2002. Using cosmogenic beryllium-7 as a tracer in sediment budget investigations. Geografiska Annaler 84A: 89-102.
Bonny, A. P., 1978. The effect of pollen recruitment processes on pollen distribution over the sediment surface of a small lake in Cumbria. Journal of Ecology 66: 385-416.

Bonny, A. P., 1980. Seasonal and annual variation over 5 years in contemporary airborne pollen trapped at a Cumbrian lake. Journal of Ecology 68: 421-441.

Brown, A. G., 1985. The potential use of pollen in the identification of suspended sediment sources. Earth Surface Processes and Landforms 10: 27-32.

Brown, A. G. \& T. A. Quine, 1999. Fluvial processes and environmental change: an overview. In Brown, A. G. \& T. A. Quine (eds), Fluvial Processes and Environmental Change. Wiley, Chichester: 1-28.

Brown, A. G., R. G. Carpenter \& D. E. Walling, 2007. Monitoring fluvial pollen transport, its relationship to catchment vegetation and implications for palaeoenvironmental studies. Review of Palaeobotany and Palynology 147: 60-76.

Brush, G. S. \& L. M. Brush, 1972. Transport of pollen in a sediment laden channel: a laboratory study. American Journal of Science 272: 359-381.

Carpenter, R. G., 2005. Fluvial pollen and its relationship to catchment vegetation: implications for suspended sediment source tracing and palaeoenvironmental investigations. Unpublished $\mathrm{PhD}$ Thesis, University of Exeter, UK.

Centre for Ecology and Hydrology, 2002. Flood Estimation Handbook CD-ROM. Wallingford.

Collins, A. L. \& D. E. Walling, 2002. Selecting fingerprint properties for discriminating potential suspended sediment sources in river basins. Journal of Hydrology 261: 218-244.

Collins, A. L., D. E. Walling \& G. J. L. Leeks, 1997a. Source type ascription for fluvial suspended sediment based on a quantitative composite fingerprinting technique. Catena 29: 1-27.

Collins, A. L., D. E. Walling \& G. J. L. Leeks, 1997b. Fingerprinting the origin of fluvial suspended sediment in larger river basins: combining assessment of spatial provenance and source type. Geografiska Annaler Series A, Physical Geography 79A: 239-254.

Crowder, A. A. \& D. G. Cuddy, 1973. Pollen in a small river basin: Wilton Creek, Ontario. In Birks, H. J. B. \& R. G. West (eds), Quaternary Plant Ecology. Blackwell Scientific Publisher, Oxford: 961-977.

David, C. \& N. Roberts, 1990. Vegetation change and pollen recruitment in a lowland lake catchment-Groby-Pool, Leics (England). Hydrobiologia 214: 305-310.

Delcourt, P. A. \& H. R. Delcourt, 1980. Pollen preservation and quaternary environmental history in the south-eastern United States. Palynology 4: 215-231.

Faegri, K. \& J. Iversen, 1989. Textbook of Pollen Analysis. Wiley, Chichester.

Fall, P. L., 1987. Pollen taphonomy in a canyon stream. Quaternary Research 28: 393-406.

Federova, K.V., 1952. Distribution of pollen and spores by flowing water. Works of the Geographical Institute of the Academy of Sciences, USSR 52: 46-72 (in Russian).

Fuller, R. M., G. B. Groom \& A. R. Jones, 1994. The Land Cover Map of Great Britain: an automated classification 
of landsat thematic mapper data. Photogrammetric Engineering and Remote Sensing 60: 553-562.

Hicks, S. \& V. P. Hyvärinen, 1986. Sampling modern pollen deposition by means of 'Tauber traps': some considerations. Pollen et Spores 28: 219-242.

Holmes, P., 1990. Differential transport of spores and pollena laboratory study. Review of Palaeobotany and Palynology 64: 289-296.

Holmes, P., 1994. The sorting of spores and pollen by water: experimental and field evidence. In Traverse, A. (ed.), Sedimentation of Organic Particles. Cambridge University Press, Cambridge: 9-32.

Hopkins, J. S., 1950. Differential pollen flotation and deposition of conifers and deciduous trees. Ecology 31: 633-641.

Jacobson, G. L. \& R. H. W. Bradshaw, 1981. The selection of sites for palaeovegetational studies. Quaternary Research 16: 80-96.

Lambert, C. P. \& D. E. Walling, 1988. Measurement of channel storage of suspended sediment in a gravel-bed river. Catena 15: 65-80.

McAndrews, J. H. \& D. M. Power, 1973. Palynology of the Great Lakes: the surface sediments of Lake Ontario. Canadian Journal of Earth Sciences 10: 777-792.

Meade, R. H., T. R. Yuzyk \& T. J. Day, 1990. Movement and storage of sediment in rivers of the United States, Canada. In Wolman, M. G. \& H. C. Riggs (eds), The Geology of North America, Vol 1. Surface Water Hydrology. Geological Society of America, Boulder, Colorado: 255-280.

Miller, J. \& T. Georgian, 1992. Estimation of fine particulate transport in streams using pollen as a seston analog. Journal of the North American Benthological Society 11: $172-180$.

Moore, P. D., J. A. Webb \& M. E. Collinson, 1991. Pollen Analysis, 2nd edn. Blackwell Science Publications, Oxford.

Nicholas, A. P. \& D. E. Walling, 1995. Modelling contemporary overbank sedimentation on floodplains: some prelimary results. In River Geomorphology. Wiley, Chichester: 131-153.

Peck, R. M., 1973. Pollen budget studies in a small Yorkshire catchment. In Birks, H. J. B. \& West, R. G. (eds), Quaternary Plant Ecology. Blackwell Scientific Publications, Oxford: 43-60.

Peck, R., 1974. Studies of pollen distribution in the oakdale catchment. Ph.D. Thesis, Cambridge University, Cambridge, UK.

Pennington, W., 1979. The origin of pollen in lake sediments: an enclosed lake compared with one receiving inflow streams. The New Phytologist 83: 189-213.

Prentice, I. C., 1985. Pollen representation, source area, and basin size-toward a unified theory of pollen analysis. Quaternary Research 23: 76-86.

Prentice, I. C., 1986. Forest-composition calibration of pollen data. In Berglund, B. E. (ed.), Handbook of Holocene Palaeoecology and Palaeohydrology. Wiley, Chichester: 799-816.

Prentice, I. C., 1988. Records of vegetation in time, space: the principles of pollen analysis. In Huntley, B. \& T. I. Webb (eds), Vegetation History. Kluwer Academic Publishers, Dordrecht: $17-42$.
Prentice, I. C. \& R. W. Parsons, 1983. Maximum likelihood linear calibration of pollen spectra in terms of forest composition. Biomectrics 39: 1051-1057.

Smirnov, A., G. L. Chmura \& M. F. Lapointe, 1996. Spatial distribution of suspended pollen in the Mississippi River as an example of pollen transport in alluvial channels. Review of Palaeobotany and Palynology 92: 69-81.

Starling, R. N. \& A. Crowder, 1981. Pollen in the Salmon River System, Ontario, Canada. Review of Palaeobotany and Palynology 31: 311-334.

Stockmarr, J., 1971. Tablets with spores used in absolute pollen analysis. Pollen et Spores 13: 615-621.

Sugita, S., M.-J. Gaillard \& A. Broström, 1999. Landscape openness and pollen records: a simulation approach. The Holocene 9: 409-421.

Tauber, H., 1974. A static non-overload pollen collector. New Phytologist 73: 359-369.

Traverse, A., 1988. Paleopalynology. Unwin Hyman, London.

Traverse, A., 1992. Organic fluvial sediment-palynomorphs and palynodebris in the lower Trinity River, Texas. Annals of the Missouri Botanical Garden 79: 110-125.

Traverse, A., 1994. Sedimentation of land-derived palynomorphs in the Trinity-Galveston Bay Area, Texas. In Traverse, A. (ed.), Sedimentation of Organic Particles. Cambridge University Press, Cambridge: 69-102.

Traverse, A. \& R. N. Ginsburg, 1966. Palynology of the surface 685 sediments of the Great Bahama Bank, as related to water 686 movement and sedimentation. Marine Geology 4: 417-459.

Walling, D. E. \& Q. He, 1994. Rates of overbank sedimentation on the floodplains of several British rivers during the past 100 Years. In Loughran, R.J., \& J. A. Kesby (eds), Variability in Stream Erosion and Sediment Transport, Vol. 224. International Association of Hydrological Scientists Publication, Wallingford: 203-210.

Walling, D. E. \& P. W. Moorehead, 1987. Spatial and temporal variation of the particle-size characteristics of fluvial suspended sediment. Geografiska Annaler Series A, Physical Geography 69: 47-59.

Walling, D. E. \& B. W. Webb, 1981. The reliability of suspended sediment load data. In Erosion and Sediment Transport Measurement. Proceedings of the Florence Symposium, June 1981, Wallingford, International Association of Hydrological Scientists Publication 133: 177-194.

Walling, D. E. \& J. C. Woodward, 1993. Use of a field based water elutriation system for monitoring the in situ particle size characteristics of fluvial suspended sediment. Water Research 27: 1413-1421.

Walling, D. E., J. C. Woodward \& A. P. Nicholas, 1993. A multi-parameter approach to fingerprinting suspendedsediment sources. In Tracers in Hydrology, Wallingford, IAHS Publication 215: 329-338.

Webb, B. W., 1980. Solute levels in the streams of the Middle and Upper Exe Basin. Unpublished $\mathrm{PhD}$ Thesis, University of Exeter.

Williams, G. P., 1989. Sediment concentration versus water discharge during single hydrologic events in rivers. Journal of Hydrology 111: 89-106. 